ISSN 1678-3921

Journal homepage: www.embrapa.br/pab

For manuscript submission and journal contents, access: www.scielo.br/pab

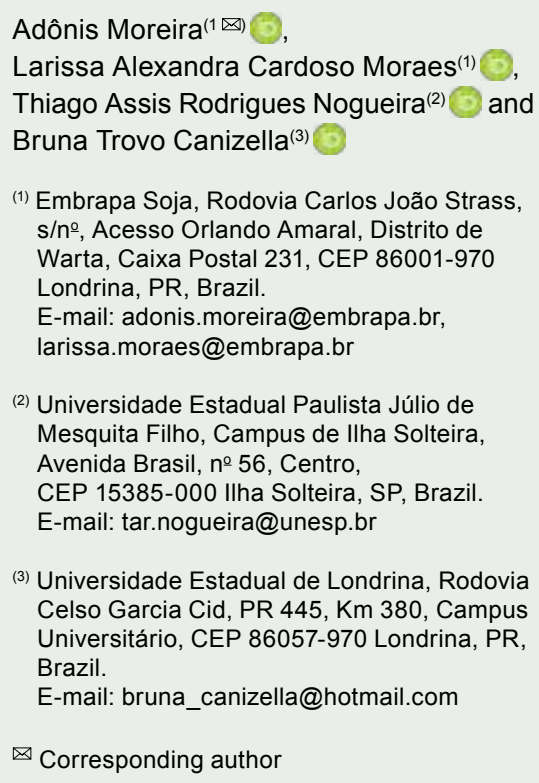

\section{Copper use efficiency in soybean cultivars}

\begin{abstract}
The objective of this work was to evaluate the effect of copper use efficiency in soybean cultivars, grown on a typical Ultisol with a high organic matter content, on soil chemical properties and on plant grain yield, nutritional state, and physiological components. The experiment was carried out in greenhouse conditions, in a $5 \times 4$ factorial arrangement, with five soybean cultivars (TMG 1066RR, BRS 360RR, NA 6262RR, BMX Turbo RR, and BRS 359RR) and four $\mathrm{Cu}$ rates $\left(0,2,4\right.$, and $\left.8 \mathrm{mg} \mathrm{kg}^{-1}\right)$. Under the studied soil conditions, the DTPA-TEA and Mehlich-1 extractants were efficient in determining available $\mathrm{Cu}$ in the soil. Regardless of the cultivars, $\mathrm{Cu}$ application increased grain yield (GY), shoot dry weight yield (SDWY), number of pods per pot, GY/SDWY ratio, photosynthetic rate, stomatal conductance, internal $\mathrm{CO}_{2}$ concentration, transpiration rate, and chlorophyll content. However, $\mathrm{Cu}$ use efficiency varied significantly among the different soybean genotypes. Except for $\mathrm{Cu}$, soil chemical attributes and foliar and grain nutrient contents are not influenced by $\mathrm{Cu}$ rates nor by soybean cultivars.
\end{abstract}

Index terms: Glycine max, DTPA-TEA, Mehlich 1, nutritional state, physiological components, yield components.

\section{Eficiência de uso de cobre em cultivares de soja}

Resumo - O objetivo deste trabalho foi avaliar o efeito da eficiência do uso de cobre em cultivares de soja, cultivadas em Argissolo típico com alto teor de matéria orgânica, sobre os atributos químicos do solo e a produção de grãos, o estado nutricional e os componentes fisiológicos das plantas. $\mathrm{O}$ experimento foi realizado em condições de casa de vegetação, em arranjo fatorial $5 \times 4$, com cinco cultivares de soja (TMG 1066RR, BRS 360RR, NA 6262RR, BMX Turbo RR e BRS 359RR) e quatro doses de $\mathrm{Cu}\left(0,2,4\right.$ e $\left.8 \mathrm{mg} \mathrm{kg}^{-1}\right)$. Nas condições de solo estudadas, os extratores DTPA-TEA e Mehlich 1 foram eficientes na determinação do $\mathrm{Cu}$ disponível no solo. Independentemente das cultivares, a aplicação de cobre aumentou a produção de grãos (PG), a produção de massa seca da parte aérea (PMSPA), o número de vagens por vaso, a relação PG/PMSPA, a taxa fotossintética, a condutância estomática, a concentração interna de $\mathrm{CO}_{2}$, a taxa transpiratória e o teor de clorofila. No entanto, a eficiência do uso de $\mathrm{Cu}$ variou significativamente entre os diferentes genótipos de soja. Exceto para $\mathrm{Cu}$, os atributos químicos do solo e os teores de nutrientes das folhas e dos grãos não são influenciados pelas doses de $\mathrm{Cu}$ nem pelas cultivares de soja.

Termos para indexação: Glycine max, DTPA-TEA, Mehlich 1, estado nutricional, componentes fisiológicos, componentes de produção.

\section{Introduction}

The introduction of the no-tillage management into crop systems has caused a gradual increase in soil organic matter (SOM), leading to a 
higher nutrient availability, water retention, and cation exchange capacity, which allow oxygen diffusion for the development of soil meso- and microfauna and, consequently, a better growth of plant roots (Fageria \& Moreira, 2011; Lourente et al., 2011). However, due to its great affinity to SOM, available copper content may decrease (Stevenson \& Fitch, 1981; Migocka \& Malas, 2018) as a result of the increased formation of complexes and chelate, which can reduce the concentration of the element in the soil solution, mainly when SOM is associated with the clay fraction, since copper retention in the solid phase is largely related to the presence of these two types of materials (Wu et al., 1999).

Copper deficiency has been reported in many agricultural soils in several parts of the world (Fageria, 2009). In South America, for example, it has been observed in cereals and legumes (Fageria et al., 2015), varying according to soil conditions and crop genotypes (Fageria, 2014). In this scenario, knowing the amount of copper required is important, since this micronutrient is essential for the healthy growth of crop plants, being responsible for activating several enzymes, with roles in photosynthesis, respiration, protein and carbohydrate metabolisms, lignification, and pollen formation (Marschner, 2012; Migocka \& Malas, 2018).

In the soil, $\mathrm{Cu}^{2+}$ ions bind directly to $\mathrm{SOM}$ through two or more functional groups, such as the carboxyl, carbonyl, and phenolic ones. For copper, immobilization occurs by the formation of a rigid inner-sphere complex in conditions of low $\mathrm{pH}$ value, differently from that observed for other metals, such as manganese, iron, and cobalt, which form an outer-sphere complex with SOM (McBride, 1997). With $\mathrm{Cu}^{2+}$, soil components are absorbed in the following preference order: manganese oxide (MnO), SOM, iron oxide $\left(\mathrm{Fe}_{2} \mathrm{O}_{3}\right)$, aluminum ion $\left(\mathrm{Al}^{3+}\right)$, and clay minerals (Wu et al., 1999). However, soil $\mathrm{MnO}$ and $\mathrm{SOM}$ are more prone to connect to $\mathrm{Cu}^{2+}$ in a non-permutable manner, since, when adsorbed by clay minerals and $\mathrm{Fe}$ and $\mathrm{Al}$ oxides, copper can be exchanged by other cations and pass to the soluble phase, which does not occur during binding to $\mathrm{MnO}$ and $\mathrm{SOM}(\mathrm{Wu}$ et al., 1999).

In plants, nutrient uptake differs according to species and cultivars, which are classified as efficient and responsive or as inefficient and responsive, for example (Moreira et al., 2015). Moreira et al. (2019) and Moreira \& Moraes (2019) found a significant increase in soybean [Glycine $\max (\mathrm{L}$.). Merr.] and wheat (Triticum aestivum L.) yield when copper was applied in a field experiment, in two growing seasons, under subtropical and greenhouse conditions. Moreira et al. (2016) highlighted that nutrient use efficiency in genotypes is a key strategy to improve soybean yield, concluding that the uptake of nutrients, including copper, varies from one soybean genotype to the other.

The objective of this work was to evaluate the effect of copper use efficiency in soybean cultivars, grown on a typical Ultisol with a high organic matter content, on soil chemical properties and on plant grain yield, nutritional state, and physiological components.

\section{Materials and Methods}

The experiment was conducted under greenhouse conditions, at an average temperature of $26^{\circ} \mathrm{C}$ and a day/night photoperiod of $13 \pm 0.5 / 11 \pm 0.5$ hours, at Embrapa Soja, in the municipality of Londrina, in

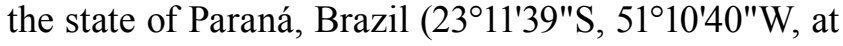
$630 \mathrm{~m}$ altitude). The soil used was an Argissolo típico (Santos et al., 2013), i.e., a typical Ultisol, collected at 0-20-cm depth, at the municipality of Ponta Grossa, also in the state of Paraná. Before the treatments were applied, soil chemical analysis showed the following attributes (Teixeira et al., 2017): $\mathrm{pH}\left(\mathrm{CaCl}_{2}\right)$ 6.5, $25.1 \mathrm{~g} \mathrm{~kg}^{-1} \mathrm{C}, 7.5 \mathrm{mg} \mathrm{kg}^{-1} \mathrm{P}$ (Mehlich-1 extractant), 0.3 $\mathrm{cmol}_{\mathrm{c}} \mathrm{kg}^{-1} \mathrm{~K}^{+}, 4.5 \mathrm{cmol}_{\mathrm{c}} \mathrm{kg}^{-1} \mathrm{Ca}^{2+}, 0.5 \mathrm{cmol}_{\mathrm{c}} \mathrm{kg}^{-1} \mathrm{Mg}^{2+}$, $0.0 \mathrm{cmol}_{\mathrm{c}} \mathrm{kg}^{-1} \mathrm{Al}^{3+}\left(\mathrm{KCl} 1.0 \mathrm{~mol} \mathrm{~L}^{-1}\right), 4.0 \mathrm{cmol}_{\mathrm{c}} \mathrm{kg}^{-1}$ $\mathrm{H}+\mathrm{Al}, 8.0 \mathrm{mg} \mathrm{kg}^{-1} \mathrm{~S}_{-} \mathrm{SO}_{4}^{-}$, cation exchange capacity (CEC) $\left(\sum \mathrm{K}^{+}, \mathrm{Ca}^{2+}, \mathrm{Mg}^{2+}, \mathrm{H}+\mathrm{Al}\right)$ of $5.51 \mathrm{cmol}_{\mathrm{c}} \mathrm{kg}^{-1}$, base saturation (V) $\left[\left(\sum \mathrm{K}^{+}, \mathrm{Ca}^{2+}, \mathrm{Mg}^{2+} / \mathrm{CEC}\right) \times 100\right]$ of $56.8 \%, 0.2 \mathrm{mg} \mathrm{kg}^{-1}$ available $\mathrm{B}$ (hot water), 1.7 mg kg-1 available $\mathrm{Cu}$ (Mehlich 1), $3.2 \mathrm{mg} \mathrm{kg}^{-1} \mathrm{Cu}$ [diethylenetriaminepentaacetic acid-triethanolamine (DTPA-TEA)], $75.5 \mathrm{mg} \mathrm{kg}^{-1}$ available Fe (Mehlich 1), $80 \mathrm{mg} \mathrm{kg}^{-1}$ available Mn (Mehlich 1), and $21.9 \mathrm{mg} \mathrm{kg}^{-1}$ available $\mathrm{Zn}$ (Mehlich 1). Soil density was $1.2 \mathrm{~g} \mathrm{~cm}^{-3}$ and clay content was $357 \mathrm{~g} \mathrm{~kg}^{-1}$.

The experimental design was completely randomized, in a $5 \times 4$ factorial arrangement, used to evaluate the response of five soybean transgenic cultivars (TMG 1066RR, BRS 360RR, NA 6262RR, BMX Turbo RR, and BRS 359RR) to four $\mathrm{Cu}$ rates $\left(0,2,4\right.$, and $\left.8 \mathrm{mg} \mathrm{kg}^{-1}\right)$, with four replicates. The choosen cultivars were obtained from different breeders, were representative of the subtropical region, showed an indeterminate cycle, and were classified in the 5.9 to 6.2 relative maturity group. 
Thirty days before planting in 3.0-kg soil clay pots, a total of $3.0 \mathrm{Mg} \mathrm{ha}^{-1}$ dolomitic lime were applied (13.5\% $\mathrm{MgO}$ and $95 \%$ effective calcium carbonate equivalent). The pots were irrigated daily with deionized water to keep the soil next to $70 \%$ of total pore volume. Ten seeds were seeded and, after harvest, two plants were left per pot.

Nitrogen was supplied by the inoculation of seeds with a cocktail of Bradyrhizobium elkanii + Bradyrhizobium japonicum. The other nutrients phosphorus, potassium, sulfur, boron, cobalt, iron, manganese, molybdenum, nickel, and zinc - were applied as recommended by Moreira et al. (2011) for experiments conducted in greenhouse conditions: 50 $\mathrm{mg} \mathrm{kg}{ }^{-1} \mathrm{P}$ (monoammonium phosphate), $0.5 \mathrm{mg} \mathrm{kg}^{-1}$ B $\left(\mathrm{H}_{3} \mathrm{BO}_{3}\right), 0.1 \mathrm{mg} \mathrm{kg}{ }^{-1} \mathrm{Mo}\left(\mathrm{Na}_{2} \mathrm{Mo}_{4} \cdot 2 \mathrm{H}_{2} \mathrm{O}\right), 0.01$ $\mathrm{mg} \mathrm{kg}{ }^{-1} \mathrm{Co}\left(\mathrm{CoCl}_{2}\right), 0.01 \mathrm{mg} \mathrm{kg}{ }^{-1} \mathrm{Ni}\left(\mathrm{NiSO}_{4} \cdot 6 \mathrm{H}_{2} \mathrm{O}\right)$, $5.0 \mathrm{mg} \mathrm{kg}{ }^{-1} \mathrm{Mn}\left(\mathrm{MnSO}_{4} .3 \mathrm{H}_{2} \mathrm{O}\right)$, and $5.0 \mathrm{mg} \mathrm{kg}^{-1} \mathrm{Zn}$ $\left(\mathrm{ZnSO}_{4} \cdot 7 \mathrm{H}_{2} \mathrm{O}\right)$. At the $\mathrm{V}_{2}$ and $\mathrm{V}_{4}$ growth stages, 50 $\mathrm{mg} \mathrm{kg}^{-1} \mathrm{~K}$ (potassium sulphate) were applied twice as topdressing fertilization, totaling $100 \mathrm{mg} \mathrm{kg}^{-1}$ in the cycle. Except for limestone, nutrients were added in solution.

At the $\mathrm{R}_{2}$ growth stage (Fehr et al., 1971), during the morning period, the third and fourth trefoils were measured, starting at the apex, with the LI-6400XT portable photosynthesis analyzer(LI-COR Biosciences, Lincoln, NE, USA). Photosynthetic rate $\left(A, \mu \mathrm{mol} \mathrm{CO}_{2}\right.$ $\left.\mathrm{m}^{-2} \mathrm{~s}^{-1}\right)$, stomatal conductance $\left(g_{s}, \mathrm{~mol} \mathrm{H}_{2} \mathrm{O} \mathrm{m} \mathrm{m}^{-2} \mathrm{~s}^{-1}\right)$, transpiration rate (Trmmol, mmol $\mathrm{H}_{2} \mathrm{O} \mathrm{m}^{-2} \mathrm{~s}^{-1}$ ), and intercellular $\mathrm{CO}_{2}$ concentration $\left(\mathrm{Ci}, \mu \mathrm{mol} \mathrm{CO}_{2} \mathrm{~mol}^{-}\right.$ $\left.{ }^{1}\right)$ were determined, and water use efficiency ( $\mu \mathrm{mol}$ $\mathrm{CO}_{2} \mathrm{~m}^{-2} \mathrm{~s}^{-1}$ ) was calculated for $A /$ Trmmol. In the same stage and leaves, the soil-plant analysis development (SPAD) index, used to indicate relative chlorophyll content, was also measured with SPAD 502 (Konica Minolta, Inc., Osaka, Japan), being later converted into chlorophyll content $\left(\mathrm{mg} \mathrm{cm}^{-2}\right)$ through the equation $\hat{y}=16.033+(7.5774 \times$ SPAD) (Fritschi \& Ray, 2007).

After measuring these variables, the same trefoils were collected from the apex (diagnostic leaf) for each treatment. They were dried in a hood with forced circulation, at $65^{\circ} \mathrm{C}$, to determine total $\mathrm{N}, \mathrm{P}, \mathrm{K}, \mathrm{Ca}, \mathrm{Mg}$, $\mathrm{B}, \mathrm{Cu}, \mathrm{Fe}, \mathrm{Mn}$, and $\mathrm{Zn}$ contents (Malavolta et al., 1997). During all the vegetative cycle, senescent leaves were collected to obtain shoot dry weight yield (SDWY). After the physiological maturation stage (R8), grain yield (GY), number of pods per pot (NPP), and number of grains per pod (NGP) were quantified. The total contents of $\mathrm{N}, \mathrm{P}, \mathrm{K}, \mathrm{Ca}, \mathrm{Mg}, \mathrm{B}, \mathrm{Cu}, \mathrm{Fe}, \mathrm{Mn}$, and $\mathrm{Zn}$ were also obtained for the grains. After harvest, soil samples from each pot were collected to detemine soil chemical attributes $\left(\mathrm{pH}, \mathrm{SOM}, \mathrm{P}, \mathrm{K}^{+}, \mathrm{Ca}^{2+}, \mathrm{Mg}^{2+}, \mathrm{H}+\mathrm{Al}\right.$, $\mathrm{Al}^{3+}, \mathrm{S}_{-} \mathrm{SO}_{4}{ }^{2-}, \mathrm{B}, \mathrm{Cu}, \mathrm{Fe}, \mathrm{Mn}$, and $\mathrm{Zn}$ ), according to the methodologies described by Teixeira et al. (2017). Available $\mathrm{Cu}$ contents in the soil were also extracted by DTPA-TEA (Lindsay \& Norvell, 1978).

Results from soil chemical attributes, yield components, physiological components $\left(A, \mathrm{C}_{\mathrm{i}}, g_{s}\right.$, Trmmol, water use efficiency, and chlorophyll content), and plant nutritional status (leaves and grains) were subjected to normality tests, analysis of variance, F-statistics, Pearson's correlation analysis, and polynomial regression, correlation, and regression, at $5 \%$ probability.

\section{Results and Discussion}

The cultivar $\times \mathrm{Cu}$ rate interactions were not significant for soil chemical attributes (Table 1). Most of the analyzed attributes $\left(\mathrm{pH}, \mathrm{C}, \mathrm{P}, \mathrm{K}^{+}, \mathrm{Ca}^{2+}\right.$, $\mathrm{Mg}^{2+}, \mathrm{SO}_{4}{ }^{2-}, \mathrm{Fe}, \mathrm{Mn}$, and $\mathrm{Zn}$ ) were above or within the range considered adequate for the development of plants in tropical conditions; the exceptions were $\mathrm{Al}^{3+}$ and potential acidity that were within the low or very low range, and available $B$ that was below the recommended range (Moreira et al., 2017b).

In the case of available $\mathrm{Cu}$, independently of the extractant used (Mehlich 1 or DTPA-TEA), there was a linear increment in $\mathrm{Cu}$ contents with the increase in nutrient rates (Figure 1). Both extractants were affected by these rates and were significantly correlated when used to determine soil nutrient availability (Figure 2). Available $\mathrm{Cu}$ contents varied from 5.6 to 7.8 $\mathrm{mg} \mathrm{kg}^{-1}$, with an average of $6.5 \mathrm{mg} \mathrm{kg}^{-1}$, with the DTPATEA extractant, and from 2.1 to $3.3 \mathrm{mg} \mathrm{kg}^{-1}$, with an average of $2.5 \mathrm{mg} \mathrm{kg}^{-1}$, with Mehlich 1, which means that DTPA-TEA extracted 2.6 times more available $\mathrm{Cu}$ than Mehlich $1(\hat{\mathrm{y}}=3.972+1.034 \mathrm{x}, \mathrm{r}=0.59$, $\mathrm{p} \leq 0.05$ ). Despite these differences, the interpretation ranges for soil $\mathrm{Cu}$ availability and the efficiency of both extractants for the interpretation of soil nutrient contents are in alignment with Tecnologias de produção de soja (2011). Even with high soil available $\mathrm{Cu}$ (Figure 2), the ranges were within those obtained 
by Moreira \& Moraes (2019) in soils with different clay and SOM contents.

GY, SDWY, GY/SDWY ratio, and NPP were influenced by the treatments, with a significant cultivar $\times \mathrm{Cu}$ rate interaction for these variables (Table 2 ). These results showed that the variation between cultivars was consistent and that the cultivars responded differently to $\mathrm{Cu}$ rates. $\mathrm{GY}$ varied from 15.0 to $25.2 \mathrm{~g}$ per pot; the highest productivity was found for the BRS 360RR cultivar, with an average of $22.4 \mathrm{~g}$ per pot, regardless of the $\mathrm{Cu}$ rate, and the lowest for NA 6262RR, with $17.6 \mathrm{~g}$ per pot. Moreira et al. $(2015,2017 \mathrm{a})$ also observed that, even when the same amount of a certain nutrient is applied to substrates, soybean cultivars adapted to the same environmental conditions can behave differently regarding GY.

The SDWY of the five evaluated cultivars varied from 29.2 to $53.5 \mathrm{~g}$ per pot in response to the $\mathrm{Cu}$ rates, with an average of $40.9 \mathrm{~g}$ per pot. Among cultivars, in general, NA 6262RR was the least productive and

Table 1. Influence of copper rates and genotypes on the chemical attributes of a typical Ultisol after cropping of soybean (Glycine max) cultivars ${ }^{(1)}$.

\begin{tabular}{|c|c|c|c|c|c|c|c|c|c|c|c|c|c|c|c|}
\hline $\begin{array}{l}\text { Cu rates } \\
\left(\mathrm{mg} \mathrm{kg}^{-1}\right)\end{array}$ & $\begin{array}{c}\mathrm{pH} \\
\mathrm{CaCl}_{2}\end{array}$ & $\begin{array}{c}\mathrm{C} \\
\left(\mathrm{g} \mathrm{kg}^{-1}\right)\end{array}$ & $\begin{array}{c}\mathrm{P} \\
\left(\mathrm{mg} \mathrm{kg}^{-1}\right)\end{array}$ & $\mathrm{K}^{+}$ & $\mathrm{Ca}^{2+}$ & $\begin{array}{l}\mathrm{Mg}^{2+} \\
-\left(\mathrm{cmol}_{\mathrm{c}}\right.\end{array}$ & $\begin{array}{l}\mathrm{Al}^{3+} \\
\left.\mathrm{kg}^{-1}\right)^{--}\end{array}$ & $\mathrm{H}+\mathrm{Al}$ & CEC & $\begin{array}{l}\mathrm{V} \\
(\%)\end{array}$ & \multirow{2}{*}{\multicolumn{3}{|c|}{----------------( $\left(\mathrm{mg} \mathrm{kg}^{-1}\right)$}} & $\mathrm{Mn}$ & $\mathrm{Zn}$ \\
\hline \multicolumn{13}{|c|}{ TMG 1066RR } & & & \\
\hline 0 & 7.0 & 27.3 & 31.1 & 0.3 & 10.1 & 1.5 & 0.0 & 2.0 & 13.9 & 85.4 & 93.0 & 0.2 & 58.8 & 219.8 & 23.1 \\
\hline 2 & 7.1 & 24.8 & 31.5 & 0.3 & 9.7 & 1.6 & 0.0 & 2.1 & 13.7 & 85.3 & 56.6 & 0.2 & 76.7 & 224.2 & 19.6 \\
\hline 4 & 7.0 & 25.4 & 30.6 & 0.4 & 9.7 & 1.6 & 0.0 & 2.0 & 13.6 & 85.3 & 66.2 & 0.2 & 78.9 & 228.8 & 20.3 \\
\hline 8 & 7.1 & 25.8 & 32.5 & 0.3 & 10.3 & 1.5 & 0.0 & 2.2 & 14.3 & 86.1 & 52.8 & 0.2 & 66.4 & 218.4 & 18.8 \\
\hline Average & 7.1 & 25.8 & 31.4 & 0.3 & 9.9 & 1.5 & 0.0 & 2.1 & 13.9 & 85.5 & 67.2 & 0.2 & 70.2 & 222.8 & 20.4 \\
\hline \multicolumn{16}{|c|}{ BRS 360RR } \\
\hline 0 & 7.1 & 25.3 & 30.0 & 0.4 & 9.8 & 1.5 & 0.0 & 2.1 & 13.6 & 85.6 & 52.8 & 0.2 & 69.5 & 206.0 & 19.6 \\
\hline 2 & 7.0 & 25.7 & 30.3 & 0.2 & 10.6 & 1.3 & 0.0 & 2.0 & 14.1 & 85.9 & 70.6 & 0.2 & 62.9 & 214.2 & 20.7 \\
\hline 4 & 7.1 & 27.1 & 31.1 & 0.2 & 10.5 & 1.4 & 0.0 & 2.1 & 14.2 & 86.0 & 43.8 & 0.2 & 62.0 & 208.6 & 20.3 \\
\hline 8 & 7.0 & 24.6 & 34.0 & 0.2 & 9.7 & 1.2 & 0.0 & 2.0 & 13.1 & 84.4 & 43.4 & 0.2 & 88.4 & 223.1 & 19.1 \\
\hline Average & 7.1 & 25.7 & 31.4 & 0.3 & 10.1 & 1.4 & 0.0 & 2.0 & 13.77 & 85.5 & 52.7 & 0.2 & 70.7 & 213.0 & 19.9 \\
\hline \multicolumn{16}{|c|}{ NA 6262RR } \\
\hline 0 & 7.1 & 26.2 & 33.6 & 0.6 & 9.5 & 1.6 & 0.0 & 2.2 & 13.8 & 85.6 & 59.5 & 0.3 & 69.8 & 208.7 & 19.9 \\
\hline 2 & 7.1 & 24.2 & 32.0 & 0.5 & 9.7 & 1.7 & 0.0 & 2.0 & 13.9 & 85.7 & 50.0 & 0.3 & 70.9 & 216.9 & 19.2 \\
\hline 4 & 7.1 & 24.8 & 31.2 & 0.5 & 9.9 & 1.7 & 0.0 & 2.1 & 14.2 & 85.9 & 69.0 & 0.3 & 67.8 & 206.6 & 19.0 \\
\hline 8 & 7.0 & 26.5 & 29.1 & 0.5 & 9.9 & 1.5 & 0.0 & 2.0 & 13.9 & 85.5 & 59.5 & 0.3 & 69.6 & 216.8 & 19.9 \\
\hline Average & 7.1 & 25.4 & 31.5 & 0.5 & 9.7 & 1.6 & 0.0 & 2.1 & 14.0 & 85.7 & 59.5 & 0.3 & 69.5 & 212.3 & 19.5 \\
\hline \multicolumn{16}{|c|}{ BMX Turbo RR } \\
\hline 0 & 7.0 & 25.8 & 27.5 & 0.4 & 9.4 & 1.6 & 0.0 & 2.0 & 13.4 & 85.1 & 47.6 & 0.3 & 77.7 & 215.1 & 18.4 \\
\hline 2 & 7.0 & 27.4 & 32.9 & 0.6 & 9.1 & 1.6 & 0.0 & 2.1 & 13.3 & 85.2 & 61.3 & 0.3 & 82.5 & 219.8 & 19.1 \\
\hline 4 & 7.0 & 26.4 & 30.9 & 0.3 & 9.6 & 1.5 & 0.0 & 2.0 & 13.3 & 85.2 & 63.0 & 0.3 & 69.7 & 207.4 & 19.3 \\
\hline 8 & 7.1 & 27.3 & 28.7 & 0.3 & 10.2 & 1.6 & 0.0 & 2.1 & 14.1 & 86.0 & 55.6 & 0.2 & 63.5 & 205.6 & 18.8 \\
\hline Average & 7.0 & 26.7 & 30.0 & 0.4 & 9.6 & 1.6 & 0.0 & 2.0 & 13.5 & 85.4 & 56.9 & 0.3 & 73.3 & 212.0 & 18.9 \\
\hline \multicolumn{16}{|c|}{ BRS 359RR } \\
\hline 0 & 7.0 & 26.2 & 32.2 & 0.3 & 10.1 & 1.6 & 0.0 & 2.0 & 13.9 & 85.7 & 62.2 & 0.3 & 79.8 & 217.0 & 19.1 \\
\hline 2 & 7.0 & 29.8 & 31.0 & 0.2 & 10.0 & 1.4 & 0.0 & 2.1 & 13.7 & 85.1 & 63.7 & 0.3 & 57.0 & 192.1 & 18.3 \\
\hline 4 & 6.8 & 25.2 & 30.0 & 0.3 & 9.1 & 1.5 & 0.0 & 2.0 & 12.8 & 84.7 & 58.4 & 0.4 & 66.0 & 212.3 & 21.6 \\
\hline 8 & 7.0 & 26.7 & 33.5 & 0.3 & 8.4 & 1.4 & 0.0 & 2.1 & 12.2 & 83.2 & 64.2 & 0.3 & 82.9 & 223.8 & 21.1 \\
\hline Average & 6.9 & 27.0 & 31.7 & 0.3 & 9.4 & 1.5 & 0.0 & 2.0 & 13.1 & 84.7 & 62.1 & 0.3 & 71.4 & 211.3 & 20.0 \\
\hline \multicolumn{16}{|c|}{ F-test } \\
\hline Cultivar (a) & $\mathrm{ns}$ & $\mathrm{ns}$ & $\mathrm{ns}$ & $\mathrm{ns}$ & $\mathrm{ns}$ & $\mathrm{ns}$ & ns & ns & $\mathrm{ns}$ & $\mathrm{ns}$ & $\mathrm{ns}$ & ns & ns & $\mathrm{ns}$ & ns \\
\hline Rates (b) & $\mathrm{ns}$ & $\mathrm{ns}$ & $\mathrm{ns}$ & $\mathrm{ns}$ & $\mathrm{ns}$ & ns & $\mathrm{ns}$ & $\mathrm{ns}$ & ns & ns & ns & $\mathrm{ns}$ & $\mathrm{ns}$ & $\mathrm{ns}$ & ns \\
\hline $\mathrm{a} \times \mathrm{b}$ & $\mathrm{ns}$ & $\mathrm{ns}$ & $\mathrm{ns}$ & $\mathrm{ns}$ & $\mathrm{ns}$ & ns & $\mathrm{ns}$ & $\mathrm{ns}$ & $\mathrm{ns}$ & ns & $\mathrm{ns}$ & $\mathrm{ns}$ & ns & $\mathrm{ns}$ & ns \\
\hline CV (\%) & 8.12 & 14.71 & 9.15 & 9.47 & 14.19 & 12 & 47 & 11.63 & 15.44 & 12.66 & 9.78 & 11.46 & 16.84 & 15.88 & 13.62 \\
\hline
\end{tabular}



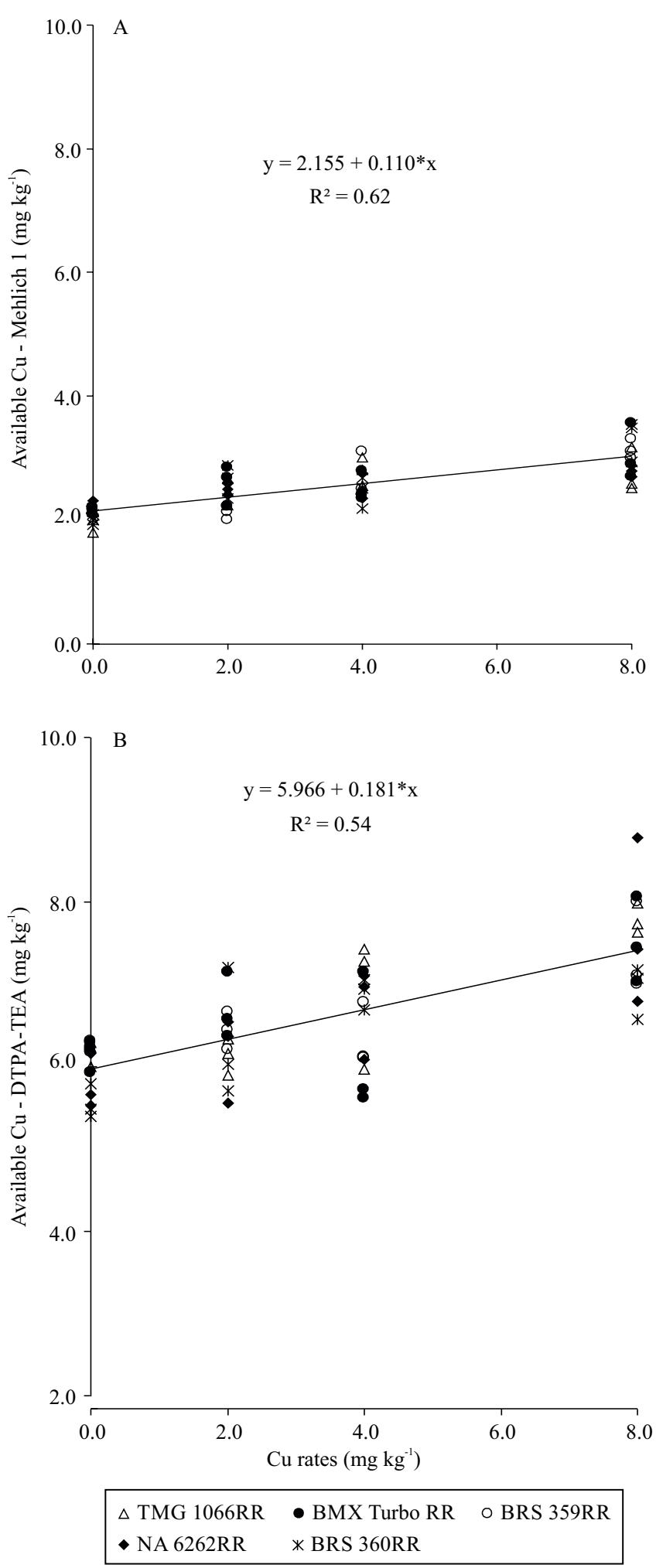

Figure 1. Available copper in the soil obtained with the Mehlich-1 (A) and diethylenetriaminepentaacetic acidtriethanolamine (DTPA-TEA) (B) extractors in response to copper rates after cropping of soybean (Glycine max) cultivars. *Significant by the F-test, at $5 \%$ probability.
TMG 1066RR, the most (Table 2). According to the regression equation $\left(\hat{\mathrm{y}}=38.260+2.090 \mathrm{x}-0.225 \mathrm{x}^{2}\right.$, $\left.\mathrm{R}^{2}=0.86, \mathrm{p} \leq 0.05\right)$, the highest SDWY was obtained with the $\mathrm{Cu}$ rate estimated at $4.6 \mathrm{mg} \mathrm{kg}^{-1}$, which is three times above the value recommended by Allen et al. (1976) and Moreira et al. (2011) as the proper amount for plant cultivation in experiments conducted in greenhouse conditions.

The GY/SDWY ratio and NPP were also influenced by $\mathrm{Cu}$ rates and soybean cultivars (Table 2), presenting a quadratic effect for the highest cultivar averages obtained with 4.0 and $3.3 \mathrm{mg} \mathrm{kg}^{-1} \mathrm{Cu}$, respectively. Among the cultivars, the highest and lowest GY/SDWY ratios of 0.56 and 0.45 were found for NA $6262 \mathrm{RR}$ and TMG 1066RR, respectively, with an average value of 0.50 . For NPP, the inverse was observed, with values ranging from 41 for NA $6262 \mathrm{RR}$ to 64 for TMG 1066RR, with an average of 53 among cultivars; BRS 360RR, BMX Turbo RR, and BRS 359RR presented intermediate values. Moreira et al. (2017a) and Moreira

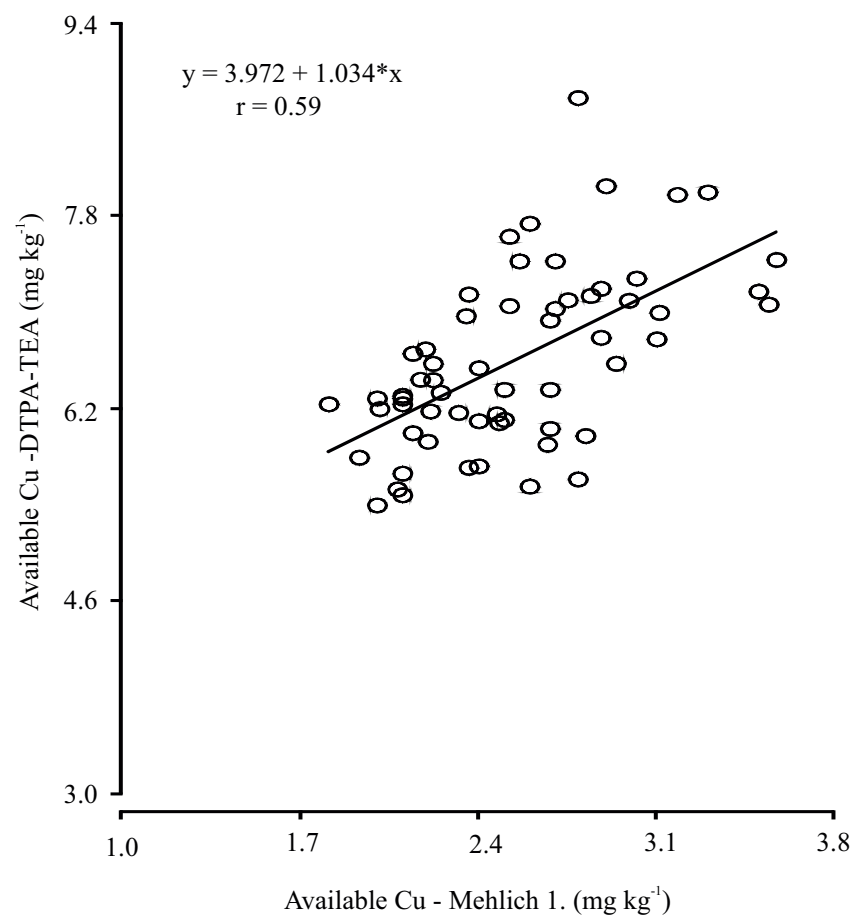

Figure 2. Relationship between the Mehlich-1 and diethylenetriaminepentaacetic acid-triethanolamine (DTPA-TEA) extractors, at pH 7.3, in determining available copper in the soil after cropping of soybean (Glycine max) cultivars. *Significant at $5 \%$ probability by the F-test. 
\& Moraes (2016) also found that NPP varied among soybean cultivars, regardless of the used fertilization. The NGP varied from 2 to 3 , a number similar to

Table 2. Grain yield (GY), shoot dry weight yield (SDWY), GY/SDWY ratio, number of pods per pot, and grains per pod of five soybean (Glycine max) cultivars in response to copper fertilization rates.

\begin{tabular}{|c|c|c|c|c|c|}
\hline \multirow{2}{*}{$\begin{array}{l}\text { Cu rates } \\
\left(\mathrm{mg} \mathrm{kg}^{-1}\right) \\
\end{array}$} & GY & SDWY & $\begin{array}{c}\text { GY/ } \\
\text { SDWY }\end{array}$ & $\begin{array}{c}\text { Pods } \\
\text { per pot }\end{array}$ & $\begin{array}{c}\text { Grains } \\
\text { per pod }\end{array}$ \\
\hline & \multicolumn{3}{|c|}{-------(g per pot)------- } & \multicolumn{2}{|c|}{---------(No.)--------- } \\
\hline \multicolumn{6}{|c|}{ TMG 1066RR } \\
\hline 0 & 19.4 & 46.1 & 0.42 & 64 & 3 \\
\hline 2 & 24.0 & 53.5 & 0.45 & 70 & 3 \\
\hline 4 & 24.1 & 49.9 & 0.48 & 61 & 3 \\
\hline 8 & 21.2 & 48.3 & 0.44 & 61 & 2 \\
\hline Average & 22.2 & 49.4 & 0.45 & 64 & 3 \\
\hline \multicolumn{6}{|c|}{ BRS 360RR } \\
\hline 0 & 20.6 & 43.4 & 0.47 & 49 & 3 \\
\hline 2 & 21.8 & 51.5 & 0.42 & 65 & 3 \\
\hline 4 & 23.7 & 48.1 & 0.49 & 61 & 2 \\
\hline 8 & 23.3 & 47.9 & 0.49 & 62 & 3 \\
\hline Average & 22.4 & 47.7 & 0.47 & 59 & 3 \\
\hline \multicolumn{6}{|c|}{ NA 6262RR } \\
\hline 0 & 16.0 & 29.2 & 0.55 & 37 & 2 \\
\hline 2 & 17.2 & 30.6 & 0.56 & 41 & 3 \\
\hline 4 & 18.3 & 34.9 & 0.52 & 48 & 2 \\
\hline 8 & 18.7 & 30.1 & 0.62 & 37 & 2 \\
\hline Average & 17.6 & 31.2 & 0.56 & 41 & 2 \\
\hline \multicolumn{6}{|c|}{ BMX Turbo RR } \\
\hline 0 & 15.0 & 33.5 & 0.45 & 40 & 2 \\
\hline 2 & 20.7 & 30.8 & 0.67 & 42 & 2 \\
\hline 4 & 21.0 & 40.0 & 0.52 & 50 & 2 \\
\hline 8 & 16.7 & 35.7 & 0.47 & 37 & 3 \\
\hline Average & 18.4 & 35.0 & 0.53 & 42 & 2 \\
\hline \multicolumn{6}{|c|}{ BRS 359RR } \\
\hline 0 & 21.2 & 38.9 & 0.54 & 53 & 3 \\
\hline 2 & 21.6 & 42.0 & 0.51 & 56 & 3 \\
\hline 4 & 25.2 & 41.5 & 0.61 & 59 & 2 \\
\hline 8 & 18.7 & 36.6 & 0.51 & 51 & 3 \\
\hline Average & 21.7 & 39.7 & 0.54 & 55 & 3 \\
\hline \multicolumn{6}{|c|}{ Average } \\
\hline 0 & 18.4 & 38.2 & 0.48 & 52 & 3 \\
\hline 2 & 21.1 & 41.7 & 0.51 & 54 & 3 \\
\hline 4 & 22.5 & 42.9 & 0.52 & 54 & 2 \\
\hline 8 & 19.7 & 40.6 & 0.48 & 50 & 3 \\
\hline Average & 20.4 & 40.9 & 0.50 & 53 & 3 \\
\hline \multicolumn{6}{|c|}{ F-test } \\
\hline Cultivar (a) & $*$ & $*$ & $*$ & * & ns \\
\hline Rate (b) & $*$ & $*$ & $*$ & $*$ & ns \\
\hline $\mathrm{a} \times \mathrm{b}$ & $*$ & $*$ & $*$ & $*$ & $\mathrm{~ns}$ \\
\hline $\mathrm{CV}(\%)^{(1)}$ & 12.52 & 13.84 & 13.51 & 16.43 & 8.17 \\
\hline
\end{tabular}

that obtained by Moreira et al. (2015) and Moreira \& Moraes (2016) for different cultivars. Fageria et al. (2010) attributed differences in NGP in leguminous plants to genetic factors, which could explain the differences between genotypes of varying origins and characteristics.

In leaves, differences were observed among cultivars for $\mathrm{N}, \mathrm{P}, \mathrm{K}, \mathrm{Ca}, \mathrm{Fe}, \mathrm{Mn}$, and $\mathrm{Zn}$ contents and for the cultivar $\times \mathrm{Cu}$ rate interaction for $\mathrm{Cu}$ content; in grains, differences were verified among cultivars for $\mathrm{Ca}$ and $\mathrm{Fe}$ contents and also for the interaction between treatments for $\mathrm{Cu}$ content (Tables 3 and 4). In leaves, nutrient contents varied from 22.2 to $35.5 \mathrm{~g} \mathrm{~kg}^{-1} \mathrm{~N}, 2.8$ to $9.9 \mathrm{~g} \mathrm{~kg}^{-1} \mathrm{P}, 13.3$ to $23.0 \mathrm{~g} \mathrm{~kg}^{-1} \mathrm{~K}, 1.7$ to $3.4 \mathrm{~g} \mathrm{~kg}^{-1}$ $\mathrm{Ca}, 3.0$ to $4.8 \mathrm{~g} \mathrm{~kg}^{-1} \mathrm{Mg}, 3.2$ to $11.7 \mathrm{mg} \mathrm{kg}^{-1} \mathrm{Cu}, 29.2$ to $122.5 \mathrm{mg} \mathrm{kg}^{-1} \mathrm{Fe}, 40.1$ to $115.5 \mathrm{mg} \mathrm{kg}^{-1} \mathrm{Mn}$, and 12.5 to $23.0 \mathrm{mg} \mathrm{kg}^{-1} \mathrm{Zn}$; in grains, from 26.2 to $40.8 \mathrm{~g} \mathrm{~kg}^{-1} \mathrm{~N}$, 4.0 to $8.0 \mathrm{~g} \mathrm{~kg}^{-1} \mathrm{P}, 15.2$ to $27.4 \mathrm{~g} \mathrm{~kg}^{-1} \mathrm{~K}, 1.6$ to $2.9 \mathrm{~g} \mathrm{~kg}^{-1}$ $\mathrm{Ca}, 1.1$ to $1.9 \mathrm{~g} \mathrm{~kg}^{-1} \mathrm{Mg}$, 3.6 to $15.7 \mathrm{mg} \mathrm{kg}^{-1} \mathrm{Cu}, 78.1$ to $185.7 \mathrm{mg} \mathrm{kg}^{-1} \mathrm{Fe}, 45.2$ to $83.4 \mathrm{mg} \mathrm{kg}^{-1} \mathrm{Mn}$, and 12.1 to $37.1 \mathrm{mg} \mathrm{kg}^{-1} \mathrm{Zn}$. Except for the $\mathrm{Cu}$ contents that varied with the $\mathrm{Cu}$ rates and for the $\mathrm{N}$ well below the contents indicated as adequate by Malavolta et al. (1997), the values obtained for $\mathrm{P}, \mathrm{K}, \mathrm{Ca}, \mathrm{Mg}, \mathrm{Fe}, \mathrm{Mn}$, and $\mathrm{Zn}$, in the present study, were similar to those reported by Moreira et al. $(2015,2016)$ for different soybean cultivars in the same environmental conditions.

Considering the average of soybean cultivars and $\mathrm{Cu}$ rates, the order of the macronutrient contents in the leaves was $\mathrm{N}>\mathrm{K}>\mathrm{P}>\mathrm{Mg}>\mathrm{Ca}$, while that of micronutrients was $\mathrm{Fe}>\mathrm{Mn}>\mathrm{Zn}>\mathrm{Cu}$ (Table 3). In the grains, the order of the macronutrient contents was $\mathrm{N}>$ $\mathrm{K}>\mathrm{P}>\mathrm{Ca}>\mathrm{Mg}$, and that of micronutrients was similar to the one observed for leaves (Table 4). Likewise, Moreira et al. (2015, 2017a) also reported higher N, $\mathrm{K}$, and $\mathrm{P}$ contents in leaves and grains. In relation to micronutrients in grains, Moreira et al. (2015) obtained a similar order, considering the average of different soybean cultivars. Among the evaluated cultivars, BRS 360RR presented the highest N, P, Ca, Fe, Mn, and Zn contents in the grains (Table 4), indicating a greater uptake efficiency, in agreement with Fageria et al. (2016), who observed that the uptake capacity of each cultivar and/or species affected the internal nutrient content of the plant. Probable divergences between the results of the present study and of other researches, such as that of Moreira \& Moraes (2016), can be explained 
by the amount of nutrients applied to the soil and by the differences among the assessed cultivars.

The analysis of variance also showed a positive effect of $\mathrm{Cu}$ rates on plant physiological attributes

Table 3. Nitrogen, phosphous, potassium, calcium, magnesium, copper, iron, manganese, and zinc contents in the leaves of five soybean (Glycine max) cultivars in response to copper fertilization rates.

\begin{tabular}{|c|c|c|c|c|c|c|c|c|c|}
\hline \multirow{2}{*}{$\begin{array}{l}\mathrm{Cu} \text { rates } \\
\left(\mathrm{mg} \mathrm{kg}^{-1}\right)\end{array}$} & $\mathrm{N}$ & $P$ & K & $\mathrm{Ca}$ & $\mathrm{Mg}$ & $\mathrm{Cu}$ & $\mathrm{Fe}$ & $\mathrm{Mn}$ & $\mathrm{Zn}$ \\
\hline & \multicolumn{5}{|c|}{ 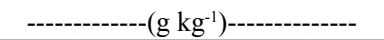 } & \multicolumn{4}{|c|}{-------( $\left(\mathrm{mg} \mathrm{kg}^{-1}\right)$--------- } \\
\hline \multicolumn{10}{|c|}{ TMG 1066RR } \\
\hline 0 & 35.6 & 3.1 & 19.9 & 2.6 & 3.7 & 3.2 & 112.8 & 66.8 & 13.5 \\
\hline 2 & 34.2 & 3.0 & 18.4 & 2.2 & 4.0 & 3.9 & 97.9 & 57.1 & 15.8 \\
\hline 4 & 31.9 & 2.9 & 17.0 & 1.8 & 3.0 & 6.8 & 81.1 & 40.1 & 17.0 \\
\hline 8 & 30.3 & 2.8 & 18.4 & 2.5 & 3.4 & 11.7 & 94.2 & 59.1 & 15.2 \\
\hline Average & 33.0 & 2.9 & 18.4 & 2.3 & 3.5 & 6.4 & 96.5 & 55.8 & 15.4 \\
\hline \multicolumn{10}{|c|}{ BRS 360RR } \\
\hline 0 & 32.1 & 9.0 & 13.8 & 2.7 & 3.2 & 3.3 & 119.8 & 92.5 & 23.0 \\
\hline 2 & 42.5 & 9.9 & 15.8 & 3.4 & 2.8 & 4.0 & 110.5 & 106.9 & 22.2 \\
\hline 4 & 31.3 & 9.2 & 13.7 & 2.7 & 3.6 & 4.6 & 88.2 & 66.7 & 19.9 \\
\hline 8 & 32.8 & 8.6 & 13.3 & 2.5 & 3.7 & 10.6 & 92.0 & 61.5 & 13.3 \\
\hline Average & 34.7 & 9.2 & 14.0 & 2.8 & 3.3 & 5.6 & 102.6 & 81.9 & 19.6 \\
\hline \multicolumn{10}{|c|}{ NA 6262RR } \\
\hline 0 & 34.4 & 4.7 & 19.7 & 3.1 & 3.1 & 5.9 & 74.1 & 115.5 & 20.5 \\
\hline 2 & 27.3 & 3.1 & 16.9 & 2.4 & 3.1 & 7.3 & 29.2 & 45.6 & 13.5 \\
\hline 4 & 22.2 & 3.4 & 17.9 & 2.7 & 3.8 & 7.6 & 39.3 & 64.7 & 16.5 \\
\hline$\underline{8}$ & 27.4 & 3.8 & 19.2 & 2.3 & 3.4 & 9.5 & 116.8 & 81.3 & 15.4 \\
\hline Average & 27.8 & 3.7 & 18.4 & 2.4 & 3.3 & 7.6 & 64.9 & 76.8 & 16.5 \\
\hline \multicolumn{10}{|c|}{ BMX Turbo RR } \\
\hline 0 & 30.5 & 4.2 & 18.6 & 2.2 & 4.1 & 4.0 & 59.7 & 68.3 & 12.3 \\
\hline 2 & 29.1 & 3.9 & 17.4 & 2.1 & 3.6 & 4.2 & 102.2 & 101.4 & 22.2 \\
\hline 4 & 29.6 & 5.0 & 21.4 & 2.0 & 3.7 & 6.8 & 98.8 & 80.7 & 19.8 \\
\hline$\underline{8}$ & 31.2 & 4.1 & 21.7 & 2.0 & 3.7 & 10.3 & 122.5 & 77.8 & 16.0 \\
\hline Average & 30.1 & 4.3 & 19.8 & 2.0 & 3.8 & 6.3 & 95.8 & 82.1 & 17.6 \\
\hline \multicolumn{10}{|c|}{ BRS 359RR } \\
\hline 0 & 28.1 & 4.8 & 21.0 & 2.0 & 3.7 & 3.6 & 104.4 & 90.7 & 16.3 \\
\hline 2 & 31.9 & 5.1 & 21.8 & 1.7 & 3.6 & 5.6 & 95.7 & 63.3 & 17.4 \\
\hline 4 & 31.0 & 5.6 & 21.5 & 1.8 & 4.8 & 6.7 & 89.8 & 82.6 & 17.0 \\
\hline 8 & 30.6 & 5.5 & 23.0 & 1.9 & 3.9 & 10.8 & 83.9 & 78.6 & 15.6 \\
\hline Average & 30.4 & 5.2 & 21.8 & 1.9 & 3.8 & 6.7 & 93.4 & 78.8 & 16.6 \\
\hline \multicolumn{10}{|c|}{ Average } \\
\hline 0 & 32.1 & 5.1 & 18.6 & 2.5 & 3.6 & 4.0 & 94.2 & 86.8 & 17.1 \\
\hline 2 & 33.0 & 5.0 & 17.9 & 2.3 & 3.4 & 5.0 & 87.1 & 74.9 & 18.2 \\
\hline 4 & 29.2 & 5.2 & 18.3 & 2.2 & 3.6 & 6.5 & 79.4 & 67.0 & 18.1 \\
\hline 8 & 30.4 & 4.9 & 19.2 & 2.3 & 3.6 & 10.6 & 101.9 & 71.6 & 15.1 \\
\hline Average & 31.2 & 5.1 & 18.5 & 2.3 & 3.6 & 6.5 & 90.7 & 75.1 & 17.1 \\
\hline \multicolumn{10}{|c|}{ F-test } \\
\hline Cultivar (a) & $*$ & $*$ & $*$ & $*$ & $\mathrm{~ns}$ & $*$ & * & * & $*$ \\
\hline Rate (b) & $\mathrm{ns}$ & $\mathrm{ns}$ & ns & ns & ns & $*$ & ns & $\mathrm{ns}$ & ns \\
\hline$\underline{a} \times \mathrm{b}$ & $\mathrm{ns}$ & $\mathrm{ns}$ & $\mathrm{ns}$ & ns & $\mathrm{ns}$ & $*$ & $\mathrm{~ns}$ & $\mathrm{~ns}$ & $\mathrm{~ns}$ \\
\hline$\overline{\mathrm{CV}(\%)^{(1)}}$ & 12.27 & 15.41 & 13.91 & 9.92 & 11.63 & 9.78 & 18.97 & 14.96 & 16.58 \\
\hline
\end{tabular}

(Table 5). The highest average values for $A, g_{s}$, Trmmol, and chlorophyll content were found for cultivar BRS 359RR, while those for $C_{i}$ and water use efficiency were obtained for TMG 100RR. In the average

Table 4. Nitrogen, phosphorus, potassium, calcium, magnesium, copper, iron, manganese, and zinc contents in the grains of five soybean (Glycine max) cultivars in response to copper fertilization rates.

\begin{tabular}{|c|c|c|c|c|c|c|c|c|c|}
\hline \multirow{2}{*}{$\begin{array}{l}\text { Cu rates } \\
\left(\mathrm{mg} \mathrm{kg}^{-1}\right)\end{array}$} & $\mathrm{N}$ & $\mathrm{P}$ & K & $\mathrm{Ca}$ & $\mathrm{Mg}$ & $\mathrm{Cu}$ & $\mathrm{Fe}$ & $\mathrm{Mn}$ & \multirow{2}{*}{$\mathrm{Zn}$} \\
\hline & \multirow{2}{*}{\multicolumn{8}{|c|}{$\frac{-}{\text { TMG } 1066 R R}$}} & \\
\hline \multicolumn{2}{|c|}{ TMG 1066RR } & & & & & & & & \\
\hline 0 & 35.6 & 5.3 & 15.5 & 2.0 & 14.2 & 6.7 & 99.9 & 67.7 & 23.0 \\
\hline 2 & 40.8 & 5.4 & 15.2 & 2.3 & 19.1 & 7.3 & 91.7 & 77.4 & 22.2 \\
\hline 4 & 23.5 & 7.0 & 17.1 & 2.5 & 17.3 & 9.1 & 94.8 & 80.1 & 29.6 \\
\hline 8 & 30.3 & 7.2 & 16.7 & 2.5 & 17.7 & 8.9 & 105.0 & 64.4 & 23.7 \\
\hline Aver & 32.5 & 6.2 & 16.1 & 2.3 & 17.1 & 8.0 & 97.8 & 72.4 & 24.6 \\
\hline \multicolumn{10}{|c|}{ BRS 360RR } \\
\hline 0 & 41.2 & 6.8 & 17.0 & 2.3 & 17.2 & 8.3 & 172.6 & 66.3 & 27.0 \\
\hline 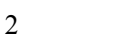 & 36.0 & 9.7 & 16.8 & 2.7 & 14.0 & 12.2 & 185.7 & 83.4 & 37.1 \\
\hline . & 31.3 & 5.5 & 18.1 & 2.3 & 15.3 & 13.7 & 111.9 & 49.6 & 26.6 \\
\hline 8 & 36.5 & 8.1 & 16.8 & 2.9 & 13.8 & 10.6 & 167.2 & 55.7 & 19.8 \\
\hline Aver & 36.3 & 7.5 & 17.2 & 2.5 & 15.1 & 11.2 & 159.4 & 63.7 & 27.6 \\
\hline \multicolumn{10}{|c|}{ NA 6262RR } \\
\hline 0 & 34.4 & 5.8 & 17.1 & 2.3 & 12.0 & 8.1 & 87.1 & 45.2 & 20.5 \\
\hline 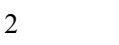 & 27.3 & 5.2 & 16.6 & 2.7 & 16.0 & 11.2 & 93.6 & 62.3 & 20.5 \\
\hline & 25.5 & 6.2 & 17.0 & 2.4 & 13.0 & 13.1 & 87.3 & 60.0 & 16.9 \\
\hline . & 27.6 & 8.0 & 17.7 & 2.3 & 15.1 & 15.7 & 96.9 & 69.3 & 26.5 \\
\hline Average & 28.7 & 6.3 & 17.1 & 2.4 & 14.0 & 12.0 & 91.2 & 59.2 & 21.1 \\
\hline \multicolumn{10}{|c|}{ BMX Turbo RR } \\
\hline 0 & 29.6 & 6.4 & 16.9 & 2.0 & 15.9 & 9.6 & 87.7 & 45.3 & 25.6 \\
\hline & 29.1 & 7.4 & 17.8 & 1.6 & 12.4 & 10.1 & 173.1 & 61.6 & 12.1 \\
\hline 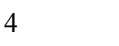 & 28.4 & 6.5 & 22.6 & 1.7 & 12.2 & 10.3 & 92.9 & 57.0 & 19.8 \\
\hline 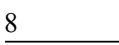 & 31.2 & 6.4 & 18.6 & 1.8 & 12.7 & 14.6 & 98.3 & 46.2 & 17.8 \\
\hline Ave & .6 & 6.7 & 19.0 & 1.8 & 13.3 & 11.2 & 113.0 & 52.5 & 18.8 \\
\hline \multicolumn{10}{|c|}{ BRS 359RR } \\
\hline 0 & 27.9 & 5.3 & 20.5 & 1.7 & 12.2 & 3.6 & 97.3 & 50.7 & 21.1 \\
\hline & 26.2 & 3.9 & 25.6 & 1.6 & 11.4 & 10.5 & 78.5 & 52.6 & 21.0 \\
\hline 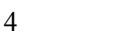 & 26.7 & 4.5 & 26.3 & 1.8 & 11.7 & 10.9 & 78.1 & 71.4 & 20.7 \\
\hline 8 & 26.7 & 4.0 & 27.4 & 1.9 & 12.8 & 13.6 & 92.0 & 71.2 & 19.9 \\
\hline Average & 26.9 & 4.4 & 25.0 & 1.8 & 12.0 & 9.7 & 86.5 & 61.5 & 20.7 \\
\hline \multicolumn{10}{|c|}{ Average } \\
\hline 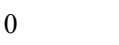 & 33.7 & 5.9 & 17.4 & 2.1 & 14.3 & 7.3 & 108.9 & 55.0 & 23.4 \\
\hline 2 & 31.9 & 6.3 & 18.4 & 2.2 & 14.6 & 10.3 & 124.5 & 67.5 & 22.6 \\
\hline 4 & 27.1 & 5.9 & 20.2 & 2.2 & 13.9 & 11.4 & 93.0 & 63.6 & 22.7 \\
\hline 8 & 30.4 & 6.7 & 19.5 & 2.3 & 14.5 & 12.7 & 111.9 & 61.3 & 21.6 \\
\hline Average & 30.8 & 6.2 & 18.9 & 2.2 & 14.3 & 10.4 & 109.6 & 61.9 & 22.6 \\
\hline
\end{tabular}

\begin{tabular}{lccccccccc} 
Cultivar (a) & $\mathrm{ns}$ & $\mathrm{ns}$ & $\mathrm{ns}$ & $*$ & $\mathrm{~ns}$ & $*$ & $*$ & $\mathrm{~ns}$ & $\mathrm{~ns}$ \\
Rate (b) & $\mathrm{ns}$ & $\mathrm{ns}$ & $\mathrm{ns}$ & $\mathrm{ns}$ & $\mathrm{ns}$ & $*$ & $\mathrm{~ns}$ & $\mathrm{~ns}$ & $\mathrm{~ns}$ \\
$\mathrm{a} \times \mathrm{b}$ & $\mathrm{ns}$ & $\mathrm{ns}$ & $\mathrm{ns}$ & $\mathrm{ns}$ & $\mathrm{ns}$ & $*$ & $\mathrm{~ns}$ & $\mathrm{~ns}$ & $\mathrm{~ns}$ \\
\hline $\mathrm{CV}(\%)^{(1)}$ & 7.99 & 9.65 & 8.87 & 9.45 & 8.23 & 7.84 & 11.42 & 10.63 & 12.57 \\
\hline
\end{tabular}

${ }^{(1)} \mathrm{CV}$, coefficient of variation. ${ }^{*}$ Significant by the $\mathrm{F}$-test, at $5 \%$ probability.

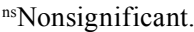


of cultivars, $A$ presented a significant correlation with GY $\left(\hat{\mathrm{y}}=6027.30+692.17 \mathrm{x}-17.93 \mathrm{x}^{2}, \mathrm{r}=0.85\right.$, $\mathrm{p} \leq 0.05)$. Among other functions, $\mathrm{Cu}$ participates in the electron transportation chain of photosystem I and in cytochrome oxidase in respiration (Malavolta et al., 1997; Fageria, 2009; Moreira et al., 2019). In the plant, approximately $50 \%$ of all $\mathrm{Cu}$ present is found in the chloroplast connected to that protein, whose proportion in relation to the number of chlorophyll molecules is 3 to 4 for 1,000 of the pigment; with

Table 5. Photosynthetic rate $(A)$, stomatal conductance $\left(g_{s}\right)$, intercellular $\mathrm{CO}_{2}\left(\mathrm{C}_{\mathrm{i}}\right)$ concentration, transpiration rate (Trmmol), water use efficiency (WUE), and chlorophyll content of five soybean (Glycine max) cultivars in response to copper fertilization rates.

\begin{tabular}{|c|c|c|c|c|c|c|}
\hline $\begin{array}{l}\text { Cu rates } \\
\left(\mathrm{mg} \mathrm{kg}^{-1}\right)\end{array}$ & $\begin{array}{c}A \\
\left(\mu \mathrm{mol} \mathrm{CO} \mathrm{Cm}^{-2} \mathrm{~s}^{-1}\right)\end{array}$ & $\begin{array}{c}\mathrm{g}_{\mathrm{s}} \\
\left(\mathrm{mol} \mathrm{m}^{-2} \mathrm{~s}^{-1}\right)\end{array}$ & $\begin{array}{c}\mathrm{C}_{\mathrm{i}} \\
\left(\mu \mathrm{mol} \mathrm{mol}^{-1}\right)\end{array}$ & $\begin{array}{c}\text { Trmmol } \\
\left(\mathrm{mmol} \mathrm{m}^{-2} \mathrm{~s}^{-1}\right)\end{array}$ & $\begin{array}{c}\text { WUE } \\
\left(\mu \mathrm{mol} \mathrm{m} \mathrm{m}^{-2} \mathrm{~s}^{-1}\right)\end{array}$ & $\begin{array}{c}\text { Chlorophyll } \\
\left(\mathrm{mg} \mathrm{m}^{-2}\right)\end{array}$ \\
\hline \multicolumn{7}{|c|}{ TMG 1066RR } \\
\hline 0 & 15.16 & 0.28 & 260.58 & 3.37 & 4.52 & 201.55 \\
\hline 2 & 16.53 & 0.32 & 261.74 & 3.30 & 5.06 & 219.93 \\
\hline 4 & 18.01 & 0.41 & 276.01 & 3.31 & 5.46 & 237.61 \\
\hline 8 & 18.62 & 0.39 & 258.81 & 4.32 & 4.37 & 206.48 \\
\hline Average & 17.08 & 0.35 & 264.28 & 3.58 & 4.85 & 216.39 \\
\hline \multicolumn{7}{|c|}{ BRS 360RR } \\
\hline 0 & 16.89 & 0.31 & 251.92 & 4.02 & 4.22 & 180.08 \\
\hline 2 & 20.71 & 0.47 & 262.52 & 5.46 & 3.81 & 210.84 \\
\hline 4 & 17.25 & 0.38 & 269.09 & 5.12 & 3.35 & 247.96 \\
\hline 8 & 15.90 & 0.30 & 254.87 & 4.56 & 3.48 & 233.13 \\
\hline Average & 17.69 & 0.36 & 259.60 & 4.79 & 3.72 & 218.00 \\
\hline \multicolumn{7}{|c|}{ NA 6262RR } \\
\hline 0 & 17.46 & 0.66 & 293.09 & 6.17 & 2.83 & 195.43 \\
\hline 2 & 18.41 & 0.38 & 252.84 & 5.30 & 3.51 & 198.46 \\
\hline 4 & 16.63 & 0.30 & 249.73 & 4.89 & 3.39 & 233.82 \\
\hline 8 & 14.51 & 0.29 & 254.55 & 4.74 & 3.11 & 221.13 \\
\hline Average & 16.75 & 0.41 & 262.55 & 5.28 & 3.21 & 212.21 \\
\hline \multicolumn{7}{|c|}{ BMX Turbo RR } \\
\hline 0 & 12.69 & 0.16 & 197.90 & 3.22 & 4.14 & 218.93 \\
\hline 2 & 15.19 & 0.19 & 207.16 & 3.99 & 3.90 & 258.71 \\
\hline 4 & 19.20 & 0.39 & 259.82 & 6.36 & 3.03 & 235.27 \\
\hline 8 & 19.24 & 0.40 & 255.69 & 6.13 & 3.17 & 222.84 \\
\hline Average & 16.58 & 0.28 & 230.14 & 4.92 & 3.56 & 233.94 \\
\hline \multicolumn{7}{|c|}{ BRS 359RR } \\
\hline 0 & 18.23 & 0.38 & 262.09 & 6.09 & 2.99 & 205.27 \\
\hline 2 & 18.68 & 0.39 & 268.56 & 6.24 & 2.99 & 262.73 \\
\hline 4 & 19.90 & 0.41 & 251.16 & 6.59 & 3.02 & 237.19 \\
\hline 8 & 17.17 & 0.33 & 250.27 & 5.64 & 3.05 & 237.36 \\
\hline Average & 18.50 & 0.38 & 258.02 & 6.14 & 3.01 & 235.64 \\
\hline \multicolumn{7}{|c|}{ Average } \\
\hline 0 & 16.99 & 0.39 & 254.01 & 4.66 & 3.93 & 225.46 \\
\hline 2 & 17.90 & 0.35 & 250.56 & 4.86 & 3.86 & 218.50 \\
\hline 4 & 17.29 & 0.35 & 260.26 & 5.17 & 3.46 & 224.79 \\
\hline 8 & 17.09 & 0.34 & 254.84 & 5.08 & 3.44 & 224.19 \\
\hline Average & 17.32 & 0.36 & 254.92 & 4.94 & 3.67 & 223.24 \\
\hline \multicolumn{7}{|c|}{ F-test } \\
\hline Cultivar (a) & $*$ & $*$ & $*$ & $*$ & $*$ & $*$ \\
\hline Rate (b) & $*$ & $*$ & $*$ & $*$ & $*$ & $*$ \\
\hline $\mathrm{a} \times \mathrm{b}$ & $*$ & $*$ & $*$ & $*$ & $*$ & $*$ \\
\hline CV $(\%)^{(1)}$ & 11.61 & 12.98 & 10.44 & 9.58 & 12.93 & 14.22 \\
\hline
\end{tabular}

${ }^{(1)} \mathrm{CV}$, coefficient of variation. *Significant by the F-test, at $5 \%$ probability. 
this, during $\mathrm{Cu}$ deficiency, there is a reduction in the concentration of plastocyanin, as well as in the activity of photosystem I (Fageria, 2009; Hänsch \& Mendel, 2009; Marschner, 2012). The effects of $\mathrm{Cu}$ on plant physiological components were also described by Migocka \& Malas (2018), evidencing the importance of $\mathrm{Cu}$ in the plant's nutritional state.

\section{Conclusions}

1. In a typical Ultisol with a high organic matter content, the grain yield, shoot dry weight yield, grain yield/shoot dry weight yield ratio, and number of pods per pot of soybean (Glycine max) cultivars are positively affected by copper fertilization, but $\mathrm{Cu}$ use efficiency varies significantly among the different soybean genotypes evaluated (TMG 1066RR, BRS 360RR, NA 6262RR, BMX Turbo RR, and BRS 359RR).

2. Photosynthetic rate, internal $\mathrm{CO}_{2}$ concentration, stomatal conductance, transpiration rate, and chlorophyll content present a positive correlation with the available $\mathrm{Cu}$ content in the soil.

3. The cultivar $\times \mathrm{Cu}$ rate interactions are not significant for the studied soil chemical attributes.

4. The Mehlich-1 and diethylenetriaminepentaacetic acid-triethanolamine (DTPA-TEA) extractants are efficient in determining available $\mathrm{Cu}$ in the soil; however, DTPA-TEA extracts 2.6 times more available $\mathrm{Cu}$ than Mehlich 1.

\section{Acknowledgments}

To Laboratório Santa Rita, for soil and plant (leaves and grains) analyses; to the staff of Soil Fertility and Microbiology of Embrapa Soja, for support in conducting the experiment; and to Conselho Nacional de Desenvolvimento Científico e Tecnológico (CNPq), for scholarship to the first author.

\section{References}

ALLEN, S.E.; TERMAN, G.L.; CLEMENTS, L.B. Greenhouse techniques for soil-plant-fertilizer research. Muscle Shoals: National Fertilizer Development Center, 1976. 57p.

FAGERIA, N.K. Mineral nutrition of rice. Boca Raton: CRC Press, 2014. 552p.

FAGERIA, N.K. The use of nutrients in crop plants. Boca Raton: CRC Press, 2009. 448p.
FAGERIA, N.K.; BALIGAR, V.C.; MOREIRA, A.; PORTES, T.A. Dry bean genotypes evaluation for growth, yield components and phosphorus use efficiency. Journal of Plant Nutrition, v.33, p.2167-2181, 2010. DOI: https://doi.org/10.1080/01904167.2010.51 9089.

FAGERIA, N.K.; GHEYI, H.R.; CARVALHO, M.C.S.; MOREIRA, A. Root growth, nutrient uptake and use efficiency by roots of tropical legume cover crops as influenced by phosphorus fertilization. Journal of Plant Nutrition, v.39, p.781-792, 2016. DOI: https://doi.org/10.1080/01904167.2015.1088020.

FAGERIA, N.K.; MOREIRA, A. The role of mineral nutrition on root growth of crop plants. In: SPARKS, D.L. (Ed.). Advances in Agronomy. Amsterdam: Elsevier, 2011. v.110, p.251-331. DOI: https://doi.org/10.1016/B978-0-12-385531-2.00004-9.

FAGERIA, N.K.; STONE, L.F.; MELO, L.C. Copper-use efficiency in dry bean genotypes. Communications in Soil Science and Plant Analysis, v.46, p.979-990, 2015. DOI: https://doi.org/10.1080/00103624.2015.1018524.

FEHR,W.R.;CAVINESS,C.E.;BURMOOD,D.T.;PENNINGTON, J.S. Stage of development description for soybeans, Glycine $\max ($ L.) Merrill. Crop Science, v.11, p.929-931, 1971. DOI: https://doi.org/10.2135/cropsci1971.0011183X001100060051x.

FRITSCHI F.B.; RAY, J.D. Soybean leaf nitrogen, chlorophyll content, and chlorophyll $a / b$ ratio. Photosynthetica, v.45, p.92-98, 2007. DOI: https://doi.org/10.1007/s11099-007-0014-4.

HÄNSCH, R.; MENDEL, R.R. Physiological functions of mineral micronutrients $(\mathrm{Cu}, \mathrm{Zn}, \mathrm{Mn}, \mathrm{Fe}, \mathrm{Ni}, \mathrm{Mo}, \mathrm{B}, \mathrm{Cl})$. Current Opinion in Plant Biology, v.12, p.259-266, 2009. DOI: https://doi.org/10.1016/j.pbi.2009.05.006.

LINDSAY, W.L.; NORVELL, W.A. Development of a DTPA soil test for zinc, iron, manganese, and copper. Soil Science Society of America Journal, v.42, p.421-428, 1978. DOI: https://doi.org/10.2136/sssaj1978.03615995004200030009x.

LOURENTE, E.R.P.; MERCANTE, F.M.; ALOVISI, A.M.T.; GOMES, C.F.; GASPARINI, A.S.; NUNES, C.M. Atributos microbiológicos, químicos e físicos de solo sob diferentes sistemas de manejo e condições de Cerrado. Pesquisa Agropecuária Tropical, v.41, p.20-28, 2011. DOI: https://doi.org/10.5216/pat. v41i1.8459.

MALAVOLTA, E.; VITTI, G.C.; OLIVEIRA, S.A. de. Avaliação do estado nutricional das plantas: princípios e aplicações. 2.ed. Piracicaba: Potafos, 1997. 319p.

MARSCHNER, P. (Ed.). Marschner's mineral nutrition of higher plants. $3^{\text {th }}$ ed. London: Academic Press, 2012. 672p.

MCBRIDE, M.; SAUVÉ, S.; HENDERSHOT, W. Solubility control of $\mathrm{Cu}, \mathrm{Zn}, \mathrm{Cd}$ and $\mathrm{Pb}$ in contaminated soils. European Journal of Soil Science, v.48, p.337-346, 1997. DOI: https://doi.org/10.1111/j.1365-2389.1997.tb00554.x.

MIGOCKA, M.; MALAS, K. Plant responses to copper: molecular and regulatory mechanisms of copper uptake, distribution and accumulation in plants. In: HOSSAIN, M.A.; KAMIYA, T.; BURRIT, D.J.; THAN, L.-S.P.; FUJIWARA, T. (Ed.). Plant micronutrient use efficiency: molecular and genomic pespectives in crop plants. London: Academic Press, 
2018. p.71-86. DOI: https://doi.org/10.1016/B978-0-0-12-8121047.00005-8.

MOREIRA, A.; FAGERIA, N.K.; GARCIA y GARCIA, A. Effect of liming on the nutritional conditions and yield of alfalfa grown in tropical conditions. Journal of Plant Nutrition, v.34, p.11071119, 2011. DOI: https://doi.org/10.1080/01904167.2011.558155.

MOREIRA, A.; MORAES L.A.C.; LARA, I.C.V.; NOGUEIRA, T.A.R. Differential response of soybean genotypes to two lime rates. Archives of Agronomy and Soil Science, v.63, p.12811291, 2017a. DOI: https://doi.org/10.1080/03650340.2016.1274976.

MOREIRA, A.; MORAES, L.A.C. Soybean response to copper applied to two soils with different levels of organic matter and clay. Journal of Plant Nutrition, v.42, p.2247-2258, 2019. DOI: https://doi.org/10.1080/01904167.2019.1655039.

MOREIRA, A.; MORAES, L.A.C. Sulfur use efficiency in soybean cultivars adapted to tropical and subtropical conditions. Communications in Soil Science and Plant Analysis, v.47, p.2208-2217, 2016. DOI: https://doi.org/10.1080/00103624.2016.1 228949.

MOREIRA, A.; MORAES, L.A.C.; FAGERIA, N.K. Variability on yield, nutritional status, soil fertility, and potassium-use efficiency by soybean cultivar in acidic soil. Communications in Soil Science and Plant Analysis, v.46, p.2490-2508, 2015. DOI: https://doi.org/10.1080/00103624.2015.1085555.

MOREIRA, A.; MORAES, L.A.C.; SCHROTH, G. Copper fertilization in soybean-wheat intercropping under no-till management. Soil \& Tillage Research, v.193, p.133-141, 2019. DOI: https://doi.org/10.1016/j.still.2019.06.001.
MOREIRA, A.; MORAES, L.A.C.; SOUZA, L.G.M.; BRUNO, I.P. Bioavailability of nutrients in seeds from tropical and subtropical soybean varieties. Communications in Soil Science and Plant Analysis, v.47, p.888-898, 2016. DOI: https://doi.org/10 $.1080 / 00103624.2016 .1146899$.

MOREIRA, A.; MOTTA, A.C.V.; COSTA, A.; MUNIZ, A.S.; CASSOL, L.C.; ZANÃO JÚNIOR, L.A.; BATISTA, M.A.; MÜLLER, M.M.L.; HAGER, N.; PAULETTI, V. (Ed.). Manual de adubação e calagem para o Estado do Paraná. Curitiba: SBCS, Núcleo Estadual do Paraná, 2017b. 482p.

SANTOS, H.G. dos; JACOMINE, P.K.T.; ANJOS, L.H.C. dos; OLIVEIRA, V.A. de; LUMBRERAS, J.F.; COELHO, M.R.; ALMEIDA, J.A. de; CUNHA, T.J.F.; OLIVEIRA, J.B. de. Sistema brasileiro de classificação de solos. 3.ed. rev. e ampl. Brasília: Embrapa, 2013. 353p.

STEVENSON, F.J.; FITCH, A. Reactions with organic matter. In: LONERAGAN, J.F.; ROBSON, A.D.; GRAHAM, R.D. (Ed.). Copper in soils and plants. Sydney: Academic Press, 1981. p.6995.

TECNOLOGIAS de produção de soja - região central do Brasil 2012 e 2013. Londrina: Embrapa Soja, 2011. 262p. (Embrapa Soja. Sistemas de produção, 15).

TEIXEIRA, P.C.; DONAGEMMA, G.K.; FONTANA, A.; TEIXEIRA, W.G. (Ed.). Manual de métodos de análise de solo. 3.ed. rev. e ampl. Brasília: Embrapa, 2017. 573p.

WU, J.; LAIRD, D.A.; THOMPSON, M.L. Sorption and desorption of copper on soil clay components. Journal of Environmental Quality, v.28, p.334-338, 1999. DOI: https://doi.org/10.2134/jeq1999.00472425002800010041x. 